assistants and auxiliaries who constitute the primary health-care teams should be encouraged.

The training programme might be as follows: 12 monthsfour months in three basic modules; 18 months-nine months in each of the two subjects taken at advanced level; six months in district hospitals working with medical auxiliaries, work being supervised by a senior district physician. The syllabus for the ordinary and advanced module in each subject must be defined. In surgery the ordinary level would include essential emergency procedures, while the advanced level would include some simple elective surgical treatment. Syllabuses might include the following components:

Ordinary level-electrolyte and fluid balance (shared with other modules); blood transfusion (shared with other modules); preoperative and operative care of intestinal obstruction; operative repair of strangulated inguinal hernia; initial management of penetrating and closed wounds of chest ; closed management of common fractures of the bones of the arms and legs, etc.

Advanced level-skin grafting of burns; excision of hydatid cysts of liver (if a common problem); management of mycetoma (if locally prevalent); management of compound fractures; simple procedures for correcting deformities resulting from poliomyelitis, etc.

Suitable text-books and manuals must be written for district practice that give precise details of standard operative procedures. The operative ability of each candidate would be certified before admission to examination and they would be required to submit a log-book of the procedures they had performed.

After completing his training, the district physician would then be posted to a district hospital with at least two other colleagues. With further experience he would be promoted to become the senior district physician in a hospital and a recognised teacher of trainees and would also be responsible for directing the primary health-care teams attached to his hospital.
Role of specialist surgeons-Specialist surgeons, working from a base in regional and national referral hospitals, must be responsible for supervising the training of district physicians, who would hold registrar (or resident) posts. When training is complete the surgeon would visit them to support them in their work and to improve their surgical skills, rather than confining himself to work within his hospital. It is to him that the district physician will refer those patients he cannot manage himself.

\section{Conclusion}

In the 'seventies the World Health Organisation and many governments, both rich and poor, have given priority to developing peripheral health services and training medical auxiliaries. An efficient system of primary care cannot be developed without recognising the crucial role of the district physician and ensuring, by suitable training and incentives, that they are capable of fulfilling it. Physicians trained in this way should provide surgical care within defined limits and receive the help and recognition of surgical colleges and institutes. Everyone who provides surgical care should be properly trained for the work that they are called upon to do, but they need not be exclusively surgeons. The surgical establishment, on the other hand, must contribute to initial and continued training and assessment. Surgeons should regard the district physicians as their equal in skill and their partners in treating disease.

\section{Reference}

${ }^{1}$ Bonte, J T P, in Health and Disease in Kenya, ed L C Vogel et al, p 75. Nairobi, East African Literature Bureau, 1974.

(Accepted 11 September 1978)

\title{
Attitudes of 40-year-old college graduates towards amniocentesis
}

\author{
SARAH BUNDEY
}

British Medical fournal, 1978, 2, 1475-1477

\begin{abstract}
Male doctors often think that almost every pregnant woman who is offered amniocentesis will gladly accept it, unless she is a Roman Catholic. Nevertheless, conversations with my nonmedical friends have shown that this is not so, and I therefore thought it would be interesting to discover the views of a group of 40-year-old women. Ideally such a group of women should be pregnant, but until widespread facilities for amniocentesis are available I thought it worth while to conduct a postal survey using my old college, Girton, as a source of women of appropriate age. I thought that the disadvantages of using such a selected group would be outweighed by the probable advantages that $(a)$ they would have some knowledge of amniocentesis, so that a brief description in a letter would be a sufficient basis for them to reach a decision; and $(b)$ they would appreciate the aims of the
\end{abstract}

\footnotetext{
Department of Clinical Genetics, Birmingham Maternity Hospital, Edgbaston, Birmingham B15 2TG

SARAH BUNDEY, DCH, MRCP, lecturer
}

survey, and therefore take the trouble to fill in and return the questionnaire. I hoped that such a survey might be useful in planning the facilities needed before amniocentesis and chromosome testing can be offered routinely.

\section{Method}

The women studied were all those who entered Girton College, Cambridge, as undergraduates in 1953-7, and who had addresses in the United Kingdom. At the end of 1977 and the beginning of 1978 each was sent a letter, an anonymous questionnaire, and a stamped addressed envelope. Each woman was asked whether she would have an amniocentesis if she were pregnant because of the increased risk of mongolism. She was given details of age-specific risks for liveborn mongols, ${ }^{1}$ and was told that the risk of losing a healthy fetus as a result of amniocentesis was about $1 \%$. As well as her and her husband's decision on amniocentesis she was asked for information on her age, marital state, number of children, any relevant handicaps in her family, and her religion. 


\section{Results}

Letters were sent to 325 women; two did not wish to participate, and no replies were received from 55 , whose addresses were presumed to be incorrect. Thus 268 women took part in the survey; their age range was $38-43$ (mean $40 \cdot 7$ ). Thirty-nine $(15 \%)$ were single; of the 227 who were married, $123(54 \%)$ had three or more children (table I),

TABLE I-Numbers of 40-year-old women who would accept or refuse amniocentesis, according to marital state and family size

\begin{tabular}{|c|c|c|c|c|c|c|c|c|c|}
\hline & \multirow{3}{*}{ Single* } & \multicolumn{7}{|c|}{ Married } & \multirow{3}{*}{ Total } \\
\hline & & \multicolumn{7}{|c|}{ No of children: } & \\
\hline & & 0 & 1 & 2 & 3 & 4 & 5 & $\geqslant 6$ & \\
\hline \multirow{2}{*}{$\begin{array}{l}\text { Would } \\
\text { accept } \\
\text { Would } \\
\text { refuse }\end{array}$} & 28 & 10 & 17 & 62 & 69 & 30 & 6 & 0 & 222 \\
\hline & 11 & 3 & 2 & 10 & 10 & 5 & 3 & 0 & 44 \\
\hline $\begin{array}{l}\text { Total No } \\
(\%)\end{array}$ & 39 (15) & $13(5)$ & $19(7)$ & $72(27)$ & $79(30)$ & $35(13)$ & $9(3)$ & 0 & $266(100)$ \\
\hline $\begin{array}{l}\text { \% In } \\
\text { general } \\
\text { population } \neq\end{array}$ & 12 & 8 & 16 & 33 & 19 & 7 & 3 & 2 & 100 \\
\hline
\end{tabular}

*None of these women had children.

†From Registrar General's figures for 1973 . $^{2}$

and $12(5 \%)$ had had or were intending to have children after the age of 38. Ten had already had an amniocentesis and one of these had had a trisomic fetus aborted. One hundred and thirty-one $(49 \%)$ were actively practising Christians, three were non-Christians, and $133 \mathrm{did}$ not actively practise a religion. Of the respondents, $222(83 \%)$ said that they would have an amniocentesis, and $44(17 \%)$ that they would not. These groups will hitherto be called group 1 and group 2. Two women could not reach a decision.

\section{WOMEN WHO WOULD HAVE AN AMNIOCENTESIS}

Of the 222 who said that they would have an amniocentesis (group 1), 88 volunteered reasons for their decision. The two main ones were that they knew of a friend, neighbour, or relative with a handicapped child or themselves worked with handicapped children, and that the demands from existing children made them realise that a handicapped child would be too much of an extra burden to the family. These opinions $\mathrm{w}$ ere partially reflected in objective differences between the two groups 35 women in group 1 volunteered that they had contact with handicapped children (table II), compared with three in group 2; and the mean family size in group 1 was $2 \cdot 2$ compared with $2 \cdot 0$ in the group 2 .

TABLE II-Numbers of handicapped children known to women who would accept or refuse amniocentesis (groups 1 and 2 respectively)

\begin{tabular}{l|c|c|c}
\hline & $\begin{array}{c}\text { Group 1 } \\
(\mathrm{n}=222)\end{array}$ & $\begin{array}{c}\text { Group 2 } \\
(\mathrm{n}=44)\end{array}$ & Total \\
\hline $\begin{array}{l}\text { First-degree relatives } \\
\text { Other relatives }\end{array}$ & 10 & 1 & $\begin{array}{c}11^{*} \\
10 \\
6\end{array}$ \\
Children of friends & 6 & 1 & $27 \ddagger$ \\
\hline Total & 25 & 0 & 2 \\
\hline
\end{tabular}

*Anencephaly (2); mongol (4); rubella syndrome (1); mental retardation (1); epilepsy (1); juvenile diabetes (1); multiple congenital abnormalities (1). Includes a husband's mongol brother, but not an aborted trisomic fetus.

\pm Sixteen of the 27 were mongols.

\section{WOMEN WHO WOULD REFUSE AN AMNIOCENTESIS}

Of the 44 women who would refuse amniocentesis (group 2), 29 volunteered reasons for their decision: 19 considered abortion unacceptable, seven thought that the risk of aborting a healthy fetus was too great, and three disliked the thought of the procedure itself. More of these women were actively practising Christians $(29 ; 66 \%)$ com- pared with group $1(101 ; 45 \%)$, six of them were Roman Catholics and 23 other denominations, mostly Anglican.

\section{VIEWS OF MARRIED WOMEN}

The proportion of single women in the group 2 was double that in group 1, and in case this unduly influenced the overall views on amniocentesis the 227 women who were married were considered separately. Of these, $194\left(85 \cdot 5^{\circ}\right.$ o) said "yes" to amniocentesis and 33 $(14 \cdot 5 \%)$ said "no."

\section{A DIFFICULT DECISION}

Thirty-six women volunteered that they found the decision on $\overrightarrow{0}$ amniocentesis an extremely difficult one. Of these, 23 finally said "yes," 11 "no," and two remained undecided. Nine women said that they would not necessarily have an abortion should a chromosomally abnormal fetus be detected; if they refused an abortion, knowledge of the abnormality would be helpful in preparing for the child's birth.

\section{Discussion}

Fifty-five women $(16 \%)$ did not reply. Because of the of anonymity of the study they could not be investigated further. Their addresses were probably out of date, for the Registrar of the Roll finds that a similar proportion do not reply when she sends out college circulars.

The graduates differed from similarly aged women in the general population (table I), not only because they were better educated, but also because they had larger families and had them later in life (the Registrar General's figures for $1973^{2}$ show that only $36 \%$ of married women have families of three or more children, and that fewer than $1 \%$ have children after the age of 38). The graduates also seemed to have more than average experience of working with handicapped children and their families. It is difficult to know whether the views of the average 40-year-old women in the population would be distributed similarly to those of the graduates. They might be less in favour of amniocentesis, for Cartwright ${ }^{3}$ has shown that more middleclass women view abortion liberally compared with working-class women. Other reasons why the findings might be unrepresentative are firstly that women may change their views when pregnant, and experience with genetic studies shows that such a change is likely to be directed against abortion; secondly, the above views were expressed in the United Kingdom during the winter of 1977-8 and may not reflect the views of women in other countries or in other eras. In Denmark, where abortion for genetic reasons has been legal for over 40 years, and is socially acceptable, few women refuse amniocentesis when it is offered on the grounds of late maternal age and the risk of mongolism. ${ }^{4}$ Possibly the views of English women will gradually change; indeed, the of proportion of women who have liberal views on abortion has doubled since 1968, when the Abortion Act was passed. ${ }^{3}$

\section{Conclusions}

Despite the above-mentioned criticisms of the study, it is interesting to know that $17 \%$ of women graduates aged $38-43$ would today refuse amniocentesis if offered it because of the increased risk of mongolism at late maternal ages. The main reason for refusal would be dislike of abortion on religious or moral grounds, a view which is independent of maternal age. The reason sometimes suggested for refusal-namely, the fear of miscarrying a healthy fetus in a long-awaited and muchwanted pregnancy in a woman unlikely to conceive again-did not appear in this survey, and is presumably a rare cause of refusal.

On the other hand, the main reasons given by most older women for accepting amniocentesis were related to their age and experience-that is, the presence of existing children who are demanding and often teenagers made them think that a

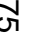
? 
handicapped child might be too much of an extra burden, and they had seen the problems of handicapped children of friends, relatives, or clients.

I thank Professor B E Ryman, the Mistress of Girton College, for permission to perform this study; Lady Bawden, the Registrar of the Roll, for her help in providing addresses of ex-Girtonians; Professor J H Edwards for his suggestions about the study; and the ex-Girtonians who participated.

\section{References}

${ }^{1}$ Hook, E B, Lancet, 1976, 2, 33.

2 The Registrar General's Statistical Review of England and Wales. London, HMSO, 1973.

${ }^{3}$ Cartwright, A, How many children? London, Routledge and Kegan Paul, 1976.

${ }^{4}$ Philip, J, Bang, J, and Madsen, M, British Medical fournal, 1977, 2, 1117.
(Accepted 14 August 1978)

\section{MATERIA NON MEDICA}

\section{Paintings on the moors}

Changing jobs is always associated with a certain amount of domestic upheaval. When the new job is 4000 miles away and involves many new commitments little time is left for a hobby like painting. But enforced abstinence from painting can be as difficult to tolerate as is going on the wagon for an alcoholic. Thankfully there are holidays. A telephone call on arriving in London, a costly visit to an art materials shop, and 48 hours later we were in the middle of the Yorkshire moors with artist Ashley Jackson.

The light in the tropics is very different from that of Europe, and especially northern England. Few artists have worked extensively in both environments. It is significant that Gauguin failed to achieve either great personal satisfaction in his work or great merit when he went first to Martinique, in the Caribbean, but later, in Tahiti, he reached the greatest possible mastery over tropical light and colours.

An integral part of landscape painting is the emotional and physical response-not only to the visual stimuli but to the heat or cold; the sounds and smells; and to the total effect on the individual of all these separate messages, integrated and amplified, or distorted, by our own associations and personalities. Ashley Jackson draws strength and inspiration from the moors - their stones and skies, the rain, the fog, and the familiar smells. But unlike that famous product of the moors, Brontë's Heathcliff, whose love was mixed with cruelty and bitterness, he is at peace with people as well as the elements and his enjoyment of both is contagious.

A London critic once wrote that in Ashley's paintings it always was raining, had just stopped raining, or was just about to rain. In a few days we saw the moors in all these moods and more, and felt in our face the wind and rain that are expressed in his enormous water colours. Although I had shivered in many parts of Britain I had never walked or painted in Yorkshire. In Barbados the temperature is a constant $70-80^{\circ} \mathrm{F}$ with a gentle breeze. On West $\mathrm{Nab}$ in wet clothes the wind provides a chill factor which makes the teeth rattle. The contrast distils the soul wonderfully and from such intense physical sufferings are wrought (one feels convinced) works of great power and feeling.

Is this why tropical paintings are sensual and northern paintings emotional ?-HENRY S FRASER (lecturer in medicine, University of the West Indies, Barbados).

\section{The last summer}

I don't know quite where the idea came from, but a group of six Cambridge medical students decided to try to go overland to Kathmandu. First we needed a vehicle, and after several offers of vehicles in a variety of conditions from the irreparable to the positively dangerous, we bought a Volkswagen minibus with a new engine for $£ 160$. Shod with Dunlop tyres (a gift which we gratefully acknowledge and incidentally the only sponsorship we were able to obtain), the minibus left England for a non-stop drive to Istanbul via France, Switzerland, Italy, Yugoslavia, and Greece; unfortunately the bus tended to break down every day. Having gone through northern Italy, and paid a token visit of homage to the Padua medical school, we arrived at the Yugoslav border at about $3 \mathrm{am}$. The border guard was most interested in our store of mint imperials, under the impression that they contained hashish. Continuing on through Yugoslavia, we were surprised to note how small the fields were-a sign that we interpreted as a lack of agricultural mechanisation. Similarly, the only well-metalled road was the international through highway.

We crossed through Greece into Turkey to find it amidst a petrol strike. The tribulations of waiting 24 hours for petrol, which, when it arrived, proved to be of a very poor quality, were amply countered by the conviviality of the Turkish people. We were rarely able to cook our own meal by the side of the road, for no sooner had we stopped than we were invited into people's homes and presented with huge meals. Having seen the Blue Mosque at Istanbul and visited the sumptuous Topkapi Palace, we headed east and south through Asia Minor, visiting the Greek and Roman ruins, which are in excellent condition and very well cared for. Before going east to India, we first went south into Syria to visit Damascus-a city rich in history, where we were able to enjoy a typically Arab bazaar. Prices dropped by a factor of about six when people realised that we were not package holiday tourists, but impoverished medical students. The Syrian people proved every bit as welcoming as their neighbours in Turkey: if they discovered us after our meal, we were still given another, much better, meal. past the town of Urfa in Kurdistan (eastern Turkey) we had a motoring accident, fortunately one in which no one was hurt and for which we were not responsible, but which killed our bus. It was very galling to get only half-way to India. More annoying was having to return without our bus and indeed only promises of reimbursement to come. Despite this, I would not discourage anyone from attempting the journey and hope to try it again myself some day.-CHARLES CLAOUÉ (medical student, London).

\section{Crossword craving}

I must be a crossword addict. Like the smoker's first cigarette or the alcoholic's first drink, I must get my first look at the crossword as early in the day as possible. A quick glance at the headlines, a groan at the weather forecast and then over to the back page. What joy, each day a virgin grid against which to pit my meagre wits. A first read through to put in the obvious answers and then a second, filling in more squares with the help of those already completed. What a redletter day it would be if I could answer all the clues without any reference to the others. But that day is still a long way off. Then on to morning surgery and the day's visits with occasional thoughts of "Mrs Oyster. 6, 2, 5." or "There can't be such a word," or "Has he made a mistake ?" (he never does). the FT index and the obituary column and then a second session with the crossword. With luck a few more answers are filled in and the quick crossword got out of the way.

After dinner comes the third and most earnest session of the day to find the last elusive answers, armed with dictionary, encyclopaedia, atlas, book of quotations, and volume of Shakespeare, and I may even enlist the aid of my wife, who has an occasional flash of genius.

What a sense of achievement when it is finished at breakfast time but what a sense of disappointment too because there will be none left to do after lunch and I will have to fall back on the medical papers.

What a sense of loss at Christmas, on Good Friday, when the newspaper boy is late, or when the printers are on strike. The craving becomes intense and I avidly look through the children's comics searching for a puzzle of some kind. The weekend competition crosswords need extra care so that no wrong answer is put in, needing messy rubbing out or else a frantic dash to the paper shop in the hope of getting another copy. And how can you mark the envelope so that it catches the eye and is picked out to be among the prizewinners? I haven't won yet and perhaps it's just as well. I could use the book tokens but if I got too many packs of cards I might become a bridge addict and my wife would never allow that.-E R G ANDERTON (general practitioner, Lancaster).
Unfortunately, our expedition was doomed to failure. As we drove

After lunch the paper is read more thoroughly with even a glance at 